\title{
Studies on the Behavioral Pharmacology of TRH-T in Cytosine Arabinoside-Induced Ataxic Mice : A Comparison with Genetically Ataxic Mice
}

\author{
Kyoko MATSUI, Yukio MANO, Masakuni MUKOYAMA, Osamu MURAMOTO, \\ Eitoku TOYOSHIMA and Kazuya ANDO. \\ National Center for Nervous, Mental and Muscular Disorders. \\ 2620, Ogawa-Higashi-Machi, Kodaira, Tokyo, 187, Japan
}

(Received for publication: March 24, 1982)

\begin{abstract}
The effects of thyrotropin releasing hormone tartrate (TRH-T) on the behavior of cytosine arabinoside (Ara-C) induced ataxic mice were studied. The ataxic mice were prepared by injecting $50 \mathrm{mg} / \mathrm{kg} /$ day subcutaneously on the $2 \mathrm{nd}$, $3 \mathrm{nd}$ and 4 th postnatal days. Spontaneous motor activities were measured with a movement spectrum analyzer (ANIMEX-2) and the degree of ataxic gait determined by an open-field study. Cerebella from these animals were subjected to histopathologic examination at 4,8 and 12 weeks of age. Ataxic gait became improved moderately and spontaneous motor activities increased slightly following administration of TRH-T. The effects of TRH-T on ataxia and spontaneous motility in the Ara-C injected mice varied with the age, and resembled those seen in weaver mice but not those in the Rolling mouse Nagoya. The results also suggest that the effects of TRH-T on the behavior of ataxic mice correlate with the extent of pathologic changes evoked in their cerebella.
\end{abstract}

Cytosine arabinoside による薬物性運動失調マウスに対する

TRH-T 投与後の行動薬理学的研究 : 遺伝性運動失調 マウスとの比較検討

松井京子・真野行生・向山昌邦 - 村本 治 - 豊島英德 - 安藤一也 国立武藏療養所神経センター

\begin{abstract}
序文
遺伝性運動失調マウスの一種である Rolling mouse Nagoya (RMN) では thyrotropin releasing hormone (L-pyroglutamyl-L-histidyl-L-prolinamide tartrate：TRH-T) 投与で著明な運動失調改善効果が
\end{abstract}

みられるが $[1,3,10]$ ，薬物性運動失調 マウスに 対する TRH-T の影響については末だ報告をみない。そこで， 我々は cytosine arabinoside (Ara-C) を投与して薬 物性運動失調 マウスを作出し (Ara-C マウス)，この Ara-C マウスについて週㱓別に病理組織学的検査を行 ない，それぞれに TRH-T を投与し，運動失調改善効 果の有無および運動量に対する影響を検討した。また, 
遺伝性運動失調マウスの $\mathrm{RMN}$ および weaver マウス に TRH-T を投与した場合と比較検討を行ない, 病理 組織学的変化との関連について言及する。

\section{材料および方法}

使用薬物：TRH-T は TRH-T $2 \mathrm{mg}$ 注射液 (武田 薬品), Ara-C は cyloside $20 \mathrm{mg}$ 注射液 (日本新薬) を使用した。

実験動物：Ara-C マウスは新生仔期 (JCL：ICR 系) に Ara-C $50 \mathrm{mg} / \mathrm{kg}$ を 3 回皮下注射して作成し, 生後 4,8 ，および 12 週齢（き）を実験に使用した。 RMN, weaver マウスは生後 8 週齢（す）を実験に使用した。

病理組織学的検索： 4,8 および 12 週龄の正常マウス とAra-C マウスを断頭後, 脳を取出し, 10\%ホルマリ ン固定, パラフィン包埋後, hematoxyline-eosine 染 色で光顕標本を作製し, 病理組織学的に検索した。

open field での計測：本実験に用いた open-field は $70 \mathrm{~cm}^{2}$ の正方形のフィールドで縦・横に七等分し, 周用 には高さ $10 \mathrm{~cm}$ の栅をつけたものである (Fig. 1)。マウ スがフィールド内の一区画を横切った場合を移動量『1』 とし，単位時間内の移動量および転倒回数を計測した。 『転倒回数/移動量』の值を転倒指数とし, 運動失調状 態の程度のパラメータとした。 4,8 および 12 週龄の Ara-C マウスそれぞれ 8 匹に TRH-T $25 \mathrm{mg} / \mathrm{kg}$ また は同量の生理食塩水を腹腔内注射し，5分毎に投与後30 分まで転倒指数を計測し，TRH-T による失調改善効 果および作用持続時間などについて 検討した。 RMN, weaver マウスについても同様の方法で実験を行なっ た。

ANIMEX-II での計測：ANIMEX-II は電磁的運動

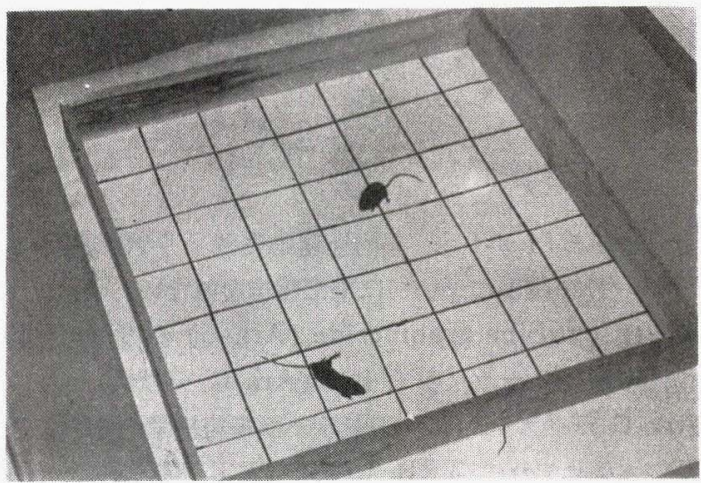

Fig. 1. Apparatus for open field study.
量測定装置でマウスの運動の变化を電気容量の変化とし て記録することができる。この ANIMEX-IIにより 4, 8 および12週齢の Ara-C マウスと正常マウスそれぞ れ10匹に TRH-T $25 \mathrm{mg} / \mathrm{kg}$ または同量の生理食塩水 を腹腔内注射し，10分毎に80分間にわたり運動量を測定 し，TRH-T の運動量に対する影響について検討した。 $\mathrm{RMN}$, weaver マウスについても同様の方法で実験を 行なった。さらに X-Yレコーダにて Ara-C マウスの $\mathrm{TRH}-\mathrm{T}$ 投与前後のケージ内での動きを歩行軌跡として 記録した。

\section{成 績}

病理組織学的検索： 4,8 および 12 週齢の Ara-C マウ スの小脳小葉の幅は正常マウスに比べほぼ半分程度であ った。各小葉の構造をみると顆粒細胞の数が正常マウス に比べて著しく減少していた。プルキンエ細胞の配列は 乱れて 2 層〜 5 層に 重層状に存在している 部位を認め た。これらの所見は 4,8 および 12 週㱓においても同様 であり, 顆粒細胞やプルキンエ細胞の変性または再生の 過程が進行した所見はこれらの時期においては認められ なかった (Fig. 2)。

open field での計測：TRH-T を各週齢の Ara-C マウスに投与すると生理食塩水投与に比べ，転倒指数の 平均值は低下するが, 有意に低下する時間が週齢により やや異なった。4 週齢の Ara-C マウスでは投与20分後 まで転倒指数の值は有意に低下し，投与 5 分以内に拈い て最低の值を示した。 8 週齢の Ara-C マウスでは投与 5 分後から15分後まで転倒指数の值は有意に低下し，投 与 5 分後から10分後の間に最低の值を示した。12週齢の Ara-C マウスでは投与 5 分後から10分後の間のみ転倒 指数の值は有意に低下し，最低の值を示した (Fig. 3)。

weaver マウスでは TRH-T 投与により投与15分後 まで転倒指数の值は有意に低下し，投与10分から15分の 間に最低の值を示した（Fig. 4, upper)。

$\mathrm{RMN}$ では投与25分後まで転倒指数の值は有意に低下 し, 投与 5 分から10分の間に最低の值を示した (Fig. 4, lower)。

ANIMEX-II での計測：正常マウスでは TRH-T 投 与は生理食塩水投与に比べ 4 週齢では投与分 40 後まで, 8 週齢では投与 60 分後まで, 12 週齢では投与40分後まで 有意に運動量が増加した (Fig. 5)。

4 週踈の Ara-C マウスは生理食塩水投与時でも運動 量は, 8,12 週齢に比べて多く, TRH-T 投与によって 


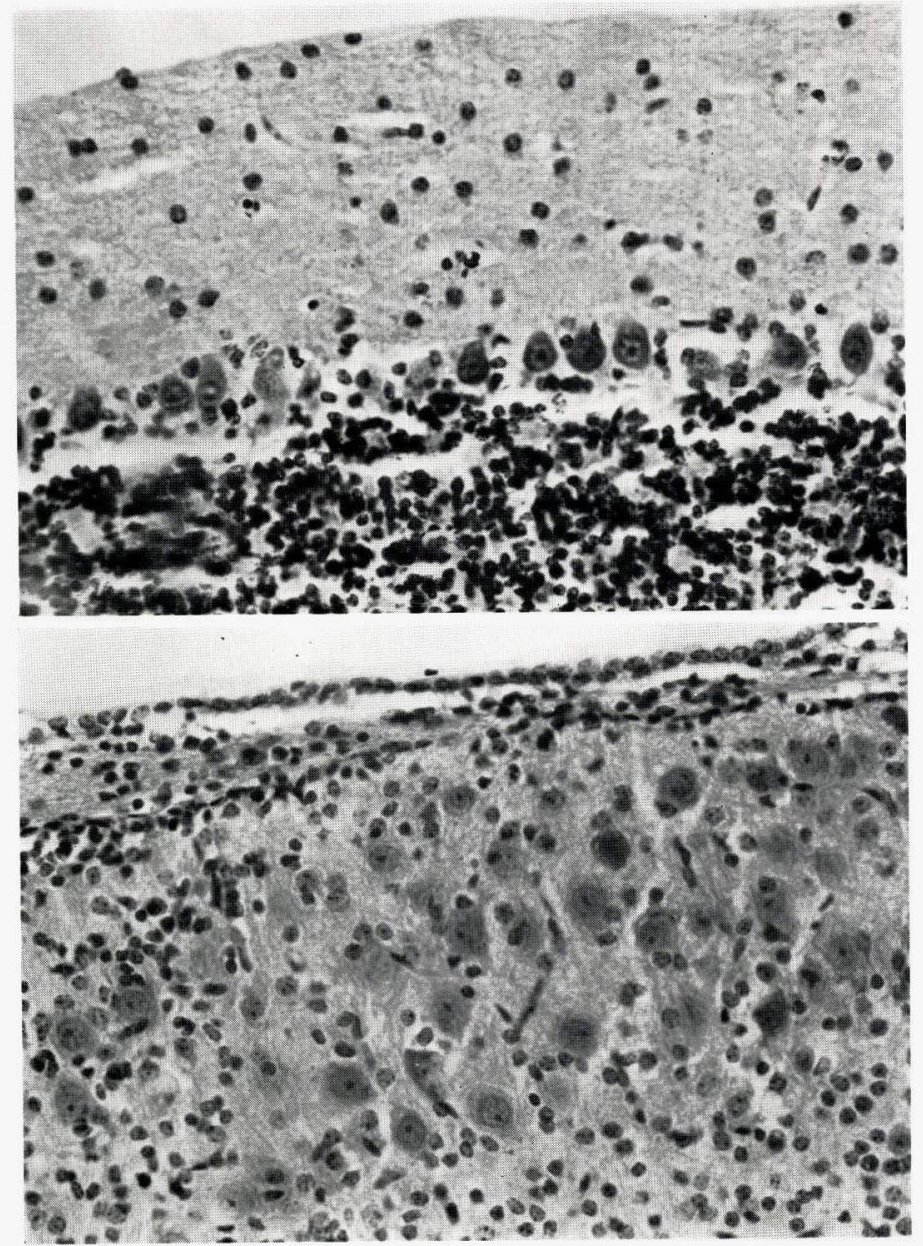

Fig. 2. Neuropathologic findings of the cerebellum.

Upper : normal mouse at 4 weeks of age

Lower : Ara-C mouse at 4 weeks of age, demonstrating loss of granule cells and persistent external granule cells.

も生理食塩水投与時に比べて，有意な運動量の増加はみ られなかった。しかし，8週粘の Ara-C マウスでは TRH-T 投与20分後まで，また，12週鈴の Ara-C マウ スでは TRH-T 投与10分後から40分後の間において， 生理食塩水投与に比べ，有意に運動量が増加した（Fig. 6)。X-Yレコーダ上にての歩行軌跡では TRH-T 投与 前のきわめて不規則な軌跡は投与 10 分後には軽減され た (Fig. 7)。

weaver マウスでは TRH-T 投与10分後においての み有意に運動量が増加し, その後徐々に運動量が低下し た (Fig. 8, upper)。
RMN では TRH-T 投与50分後まで有意に運動量が 増加し, 投与 60 分後から70分後にかけて再び有意に運動 星が増加した（Fig. 8, lower)。

$$
\text { 考察 }
$$

Ara-C マウスの小脳の病理組織学的変化は遺伝性運 動失調 マウスのうちでは顆粒細胞の欠損を特徴とする weaver マウス $[4]$ と比較的類似していた。TRH-T の 薬理学的効果もまた両マウスで類似し, 中等度の運動失 調の改善と軽度の運動量の増加を示したが,このよらな 

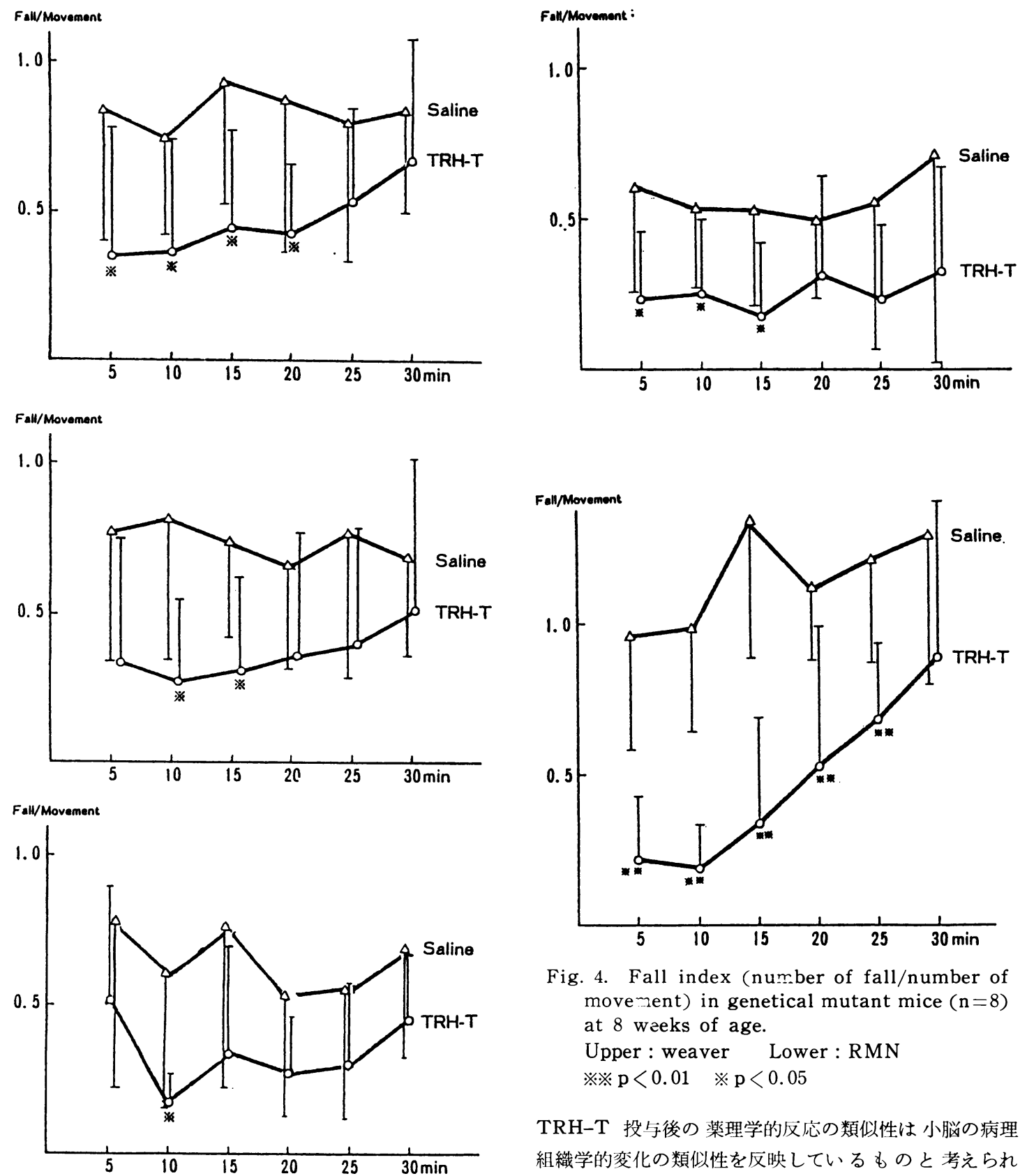

Fig. 4. Fall index (number of fall/number of movement) in genetical mutant mice $(n=8)$ at 8 weeks of age.

Upper : weaver Lower : RMN $※$ $\mathrm{p}<0.01 \quad \mathrm{p}<0.05$

$\mathrm{TRH}-\mathrm{T}$ 投与後の 薬理学的反応の類似性は小脳の病理 組織学的变化の類似性を反映しているものと考えられ た。

$\mathrm{RMN}$ は小脳におけるアミノ酸伝達物質の異常と中枢 神経系の多くの部位でのカテュールアミン 合成酵素 (tyrosine hydroxylase : TH) 活性の上昇が認められ ているが $[8], \mathrm{RMN}$ のように小脸の病理組織学的変化 の乏しいマウス[6]の方が weaver マウス, Ara-C マウ スのよらに小脳の病理組織学的変化のはっきりしたマウ 

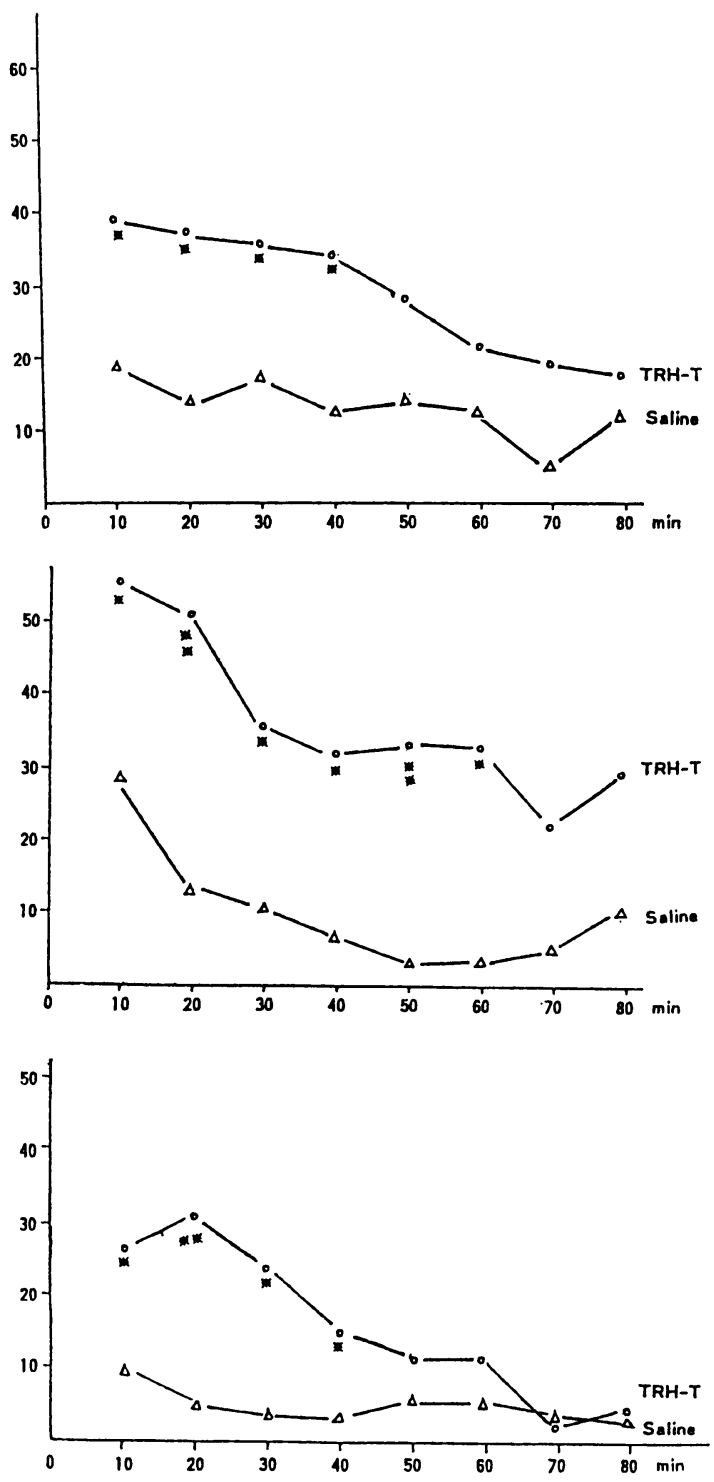

Fig. 5. Total length of movements after injections of TRH-T and saline $(n=10)$.

Upper : normal mice at 4 weeks of age. Middle : normal mice at 8 weeks of age. Lower : normal mice at 12 weeks of age. $※$ ※ $<0.01 \quad \mathbf{p}<0.05$

スに比ベ TRH-T の薬理学的効果がより明確に発現す る可能性があると考えられた。

正常マウスでは生理的食塩水投与後の運動量について 4,8 および 12 週齢時を比べてみると加齢に伴なって運 動量が低下するが，この傾向は Ara-C マウスについて も同様であった。しかし，4 週龄時には生理食塩水投与
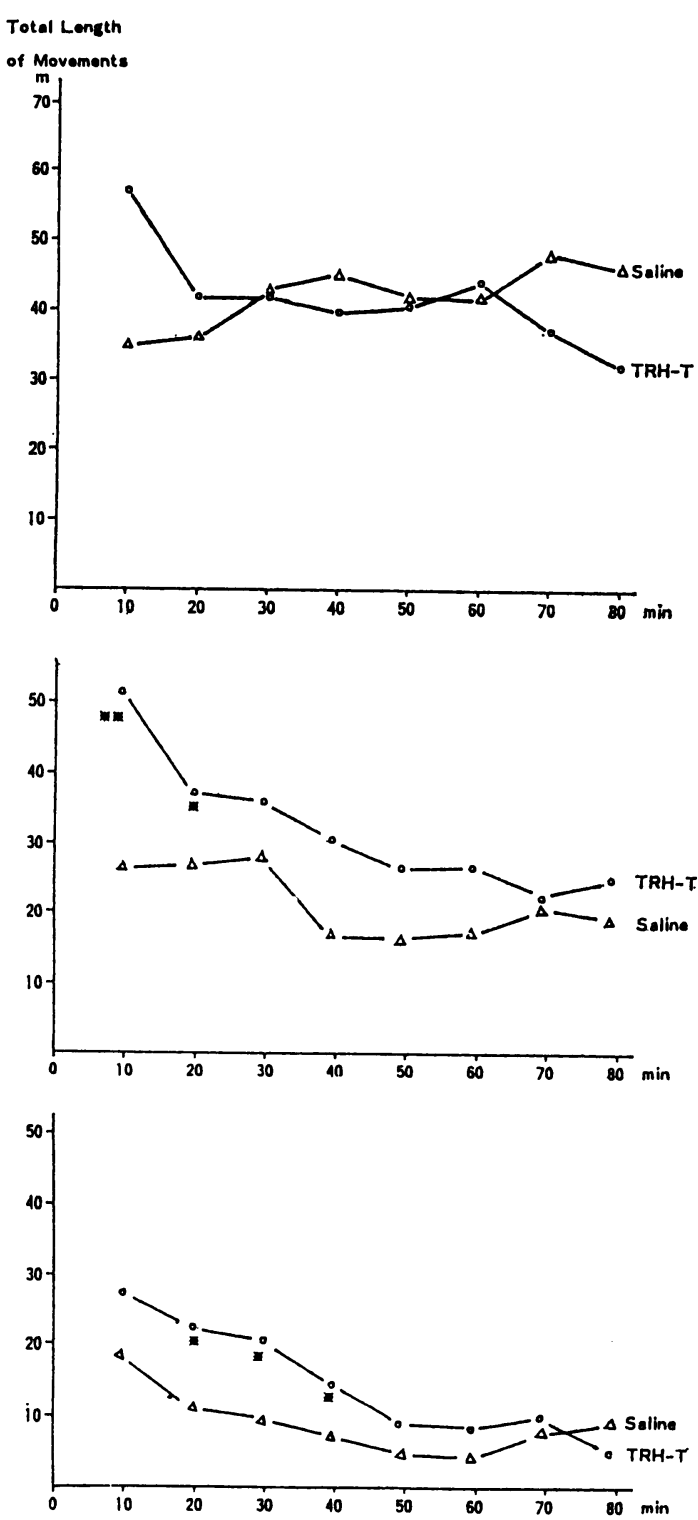

Fig. 6. Total length of movements after injection of TRH-T and saline $(n=10)$.

Upper : Ara-C mice at 4 weeks of age.

Middle : Ara-C mice at 8 weeks of age.

Lower : Ara-C mice at 12 weeks of age. $※$ ※ $<0.01 \quad \mathrm{p}<0.05$

時の運動量は Ara-C マウスの方が正常マウスに比べて 多く，より活発な運動を示した。薬物投与による動物の 運動量の異常増加に関しては methylazoxymethanol (MAM) を妊娠 14日目のラットに投与し，生まれた小 頭症ラットに拈いても認められたといら報告があるが 

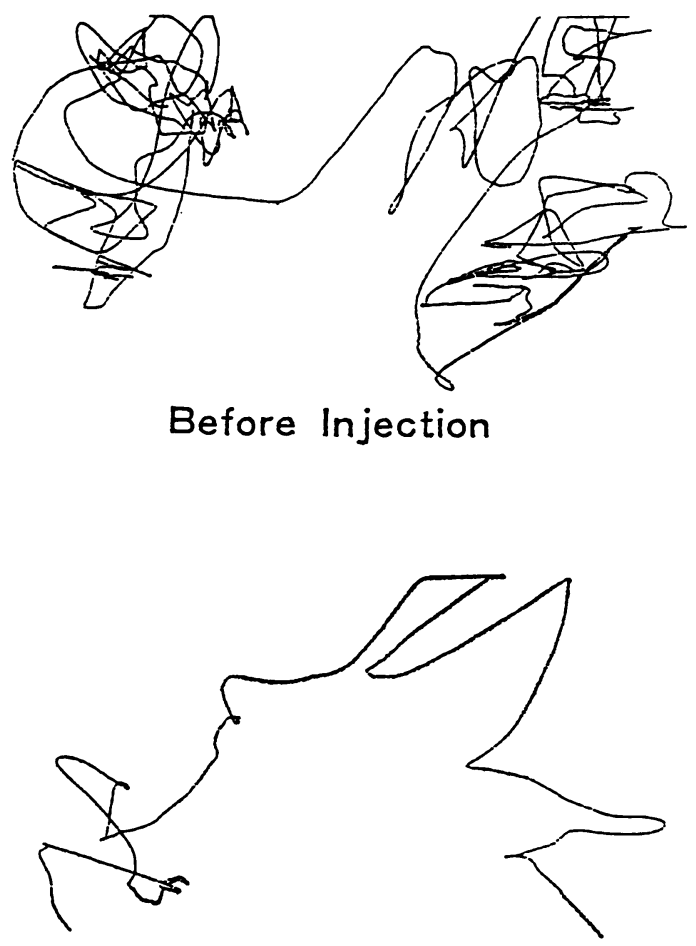

After Injection

Fig. 7. Comparison of loci of movement before and after injection of TRH-T in Ara-C mice.

(第16回, 日本実験動物学会, 1981), このような現象が どのような機序に基づいているのか今後の検討が必要で あろら。

正常マウスでは，4，8 および 12 週齢時において TRH-T 投与後少なくとも 40 分間は生理的食塩水投与に 比べ有意に運動量が増加したが Ara-C マウスでは全週 齢期間を通じて TRH-T 投与後も正常マウスほどには 有意な運動量の増加はみられなかった。この傾向はとく に幼若なマウスほど著明であった。一方，TRH-T 投与 による運動失調改善効果は幼若マウスほど失調改善傾向 がより明確で効果の持続時間も長く, 加龄による薬理学 的反応の差がみられた。しかし, 小脳における病理組織 学的所見では加龄による明らかな差はみられなかった。 Ara-C マウスの脳内カテュールアミンの生化学的検索 では小脳 NA，5:HT 濃度は，10，20日目で対照に比べ て増加を認め, 特に70日目で DNA あたりの $5 \mathrm{HT}$, NA 濃度は対照群の 6 倍の増加が認められ，加齢による Ara-C マウスの小脸の生化学的変化が認められたとさ れている $[11]$ 。このようなことが TRH-T の薬理学的
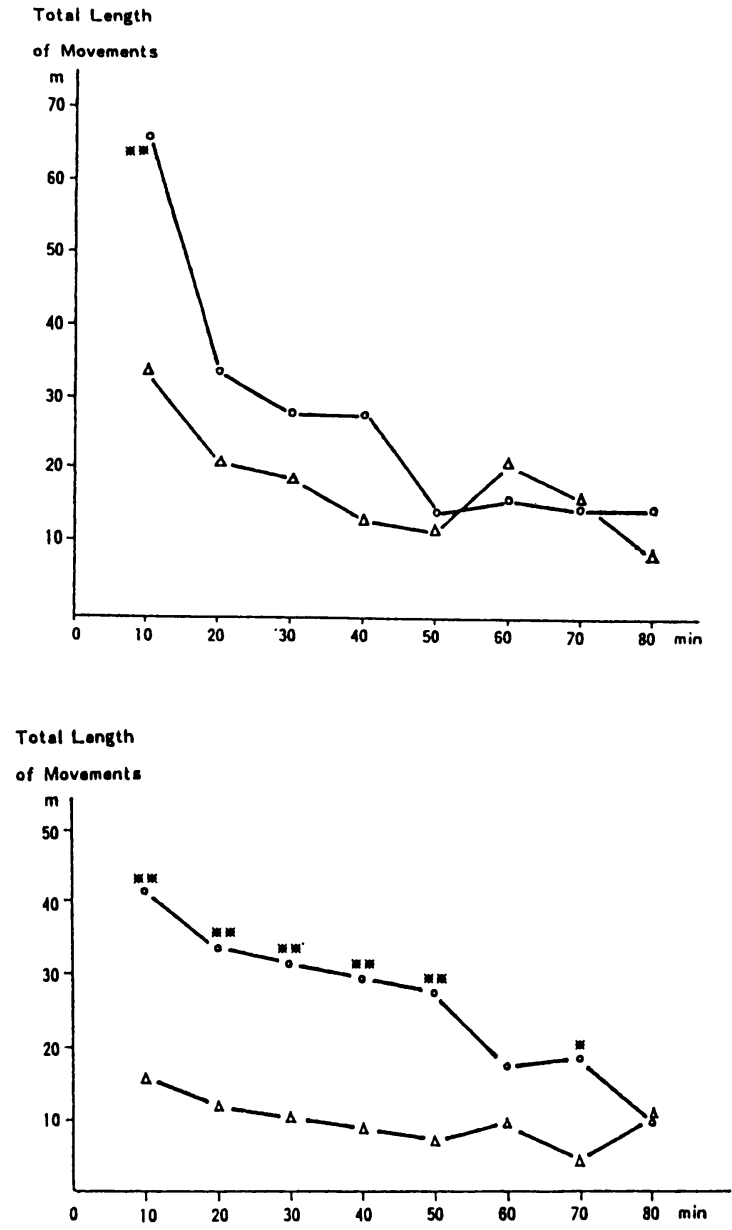

Fig. 8. Total length of movements after injection of TRH-T and saline $(n=10)$.

Upper : weaver Lower : RMN $※$ ※ $<0.01 \quad \mathrm{p}<0.05$

効果の発現にも影響を及ぼし週蹂による差が生じたとも 考えられた。

TRH-Tを側坐核に直接注入することによって惹起さ れる運動量元進作用は haloperidol p pimozide の注 入により抑制されることから TRH-T の自発運動元進 作用は主として大脳辺縁系の DA ニューロン終末から $\mathrm{DA}$ の遊離促進に由来するといわれている $[5]$ 。 $\mathrm{RMN}$ では TRH-T による運動量六進は正常マウスと同程度 であるのに対し,Ara-C マウスおよび weaverはTRHT投与による運動量六進が少ないことから DA ニューロ ンの遊離機構の異常などの関連も考えられる。

TRH-Tの運動失調改善効果について RMN では NA の代謝回転の促進によるとの説も提唱されている $[2] 。$ 
しかし， RMNを含め運動失調マウスの小脳における生 化学的検索ではNA の過剩蓄積がなく, 逆に代謝回転 は六進し，このよらな代謝回転は weaverはより高度で Ara-Cマウスは中等度, RMNでは軽度といら報告もあ る[7]。この生化学的検索結果からは TRH-T の運動失 調改善効果と小脳の NA 代謝異常とは必ずしも平行し ないといえる。TRH の中枢作用は多彩であり, 運動失 調改善効果の発現のメカニズムにはNA 代謝回転の促 進以外の機序についても今後さらに検討する必要がある と思われる。

いづれにしても，薬物性運動失調マウス（Ara-C マ ウス）にも遺伝性運動失調 マウスと同様に TRH-T 投 与による運動失調改善効果が今回の実験により確かめら れた。TRH-Tの運動失調改善の作用機序が解明されれ ばヒトの運動失調症の病態解明にも役立つと考学られ， さらに詳細に検索する必要がある。

Ara-C マウスは小脳の低形成以外飞網膜の形成異常, 成長抑制なども認められている[9]。しかし，他の遺伝 性運動失調マウスに比べると飼育が簡単であり, 生存率 がよく神経疾患の病態モデル動物の研究には適した運動 であると考えられる。

\section{要 約}

マウスの新生仔期にcytosine arabinoside $50 \mathrm{mg} / \mathrm{kg}$ を 3 回皮下注射して作成した運動失調 マウス（Ara-C マウス）に TRH-T $25 \mathrm{mg} / \mathrm{kg}$ を週齢別に腹腔内注射 し，運動失調に対する効果および運動量に対する影響を open field 拈よび ANIMEX-II により行動薬理学的 に検討した。さらに週路別に小脳の病理組織学的変化に ついても検討を加えた。TRH-T 投与により Ara-C マ ウスの運動失調は中等度の改善を示し, 幼若な Ara-C マウスの方が成獣の Ara-C マウスよりも運動失調改善 の傾向が著しく、 TRH-T 投与による運動量の増加は 逆に成獣の Ara-C マウスの方がより多く週龄により TRH-Tの楽理学的効果の差異が認められた。しかし,
加路による明らかな病理組織学的所見の変化は認められ なかった。Ara-Cマウスの TRH-T 投与による行動楽 理学的反応は遺伝性運動失調マウスの weaver マウスと 類似し, Rolling mouse Nagoya とは異なっていた が, これは小脳の病理組織学的変化の相違によるものと 考えられた。

\section{文献}

［1］足立皓岑 - 小長谷正明 - 室賀辰夫・満間照典 - 仁瓶礼之 ・ 高柳哲也 - 祖父江逸郎 - 織田銍一 - 亀山義郎 (1977). Thyrotropin releasing hormone 投与による Rolling mouse Nagoya の失調性歩行への影響, 医学のあゆみ. 101, 74-75.

[2] 小長谷正明 - 高柳哲也 - 室賀辰夫 - 足立皓岑 - 祖父江逸郎 (1980). Rolling mouse Nagoya の脳内ノルアドレナリ ンと thyrotropin releasing hormone の影響, 臨床神経. 20, $181-188$.

[3] 松井京子. 真野行生 - 豊島英徳・安藤一也 (1980)。各種 遗伝性運動失調 マウスに対する TRH 投与の影響につ、 て. 国立武藏燎養所神経センター年報 第 3号, 141-143.

[4]御子柴克彦 (1979). 運動失調モデル—遺伝性小脳変性 症マウス—-(weaver, staggerer, reeler, nervous, pcd). 神経進歩, 23, 918-936.

[5] Miyamoto, M., and Nagawa, Y. (1977). Mesolimbic involvement in the locomotor stimulant action of thyrotropin releasing hormone (TRH) in rats. Eur. J. Pharmacol., 44, 143-152.

[6]向山昌邦・水野恵介 (1976). Rolling mouse Nagoya の 小脑一光䫓的㧍よび電䫓的研究——最新医学, 31 , $233-238$.

[ 7 ] Muramoto, O., Ando, K., and Kanazawa, I. (1982). Central noradrenaline metabolism in cerebellar ataxic mice. Brain Res. 237, 387-395.

[8] Muramoto, O., Kanazawa, I., and Ando, K. (1981). Neurotransmitter abnormality in Rolling mouse Nagoya, an ataxic mutant mouse. Brain Res., 215, 295-304.

[9] Shimada, M., Wakaizumi, S., and Kasubuchi, Y. (1973). Cytosine arabinoside and rosette formation in mouse retina. Nature, 256, 151-152.

[10］祖父江逸郎（1977）. 視床下部ホルモンと中枢機能との 新 し、接点—TRH と運動失調との関連をめぐって。臨床 神経, 17, 791-799.

[11] 辻 元宏 - 岩瀬則文 - 佐藤啓二 ・高橋三郎 - 島田司己 (1979). Cytosine arabinoside 投与による小脎形成不全 マウスの脳内物質の変化と組織化学. 神経化学, 18,320323. 